\title{
The Role of Perceived Environmental Uncertainty on the usage of Strategic Management Accounting Techniques among Nigerian Manufacturing firms
}

\author{
OJUA, Olusegun Michael \\ Nigeria. \\ DOI - http://doi.org/10.37502/IJSMR.2021.4408
}

Department of Accounting, College of Business and Social Sciences, Unicaf University, Malawi,

\begin{abstract}
The objective of this research paper is to review the role of perceived environmental uncertainty (PEU) in the usage of SMATs by Nigerian manufacturing firms given the level of competition in the sector. To compete well, management decisions are influenced by the external environment due to the need for relevance. Using a sample of One Hundred and Forty Seven manufacturing firms and their accounts personnel as respondents, copies of questionnaires were distributed to gather primary data, the Correlation Coefficient and other simple statistical tools of analysis calculated. The first hypothesis shows ranking of 0.56 and 0.99 all above 0.5 level of acceptance, while the second hypothesis comparing PEU factors on the SMATs usage with z-score all above the " 3 " mean score. The results indicated significance of PEU in the use of SMATs by the firms. The findings of the study will have implications on the firms 'decision on the usage of SMATs. As a result of this research, it can be concluded that PEU factors are influencing the usage of SMATs among Nigerian Manufacturing firms.
\end{abstract}

Keywords: Perceived Environmental Uncertainty, Strategic Management Accounting, SMAT usage.

\section{Introduction}

The failure of Traditional Management Accounting Techniques (TMATs) to address competition shocks and strategic choices made the usage of Strategic Management Accounting Techniques (SMATs) for effective decision making and performance evaluation inevitable in dynamic business environments (Cadez \& Guilding, 2008; Sidhu \& Roberts, 2008). While manufacturing firms still rely on TMATs for internal operation analysis (Ahmad \& Leftesi, 2014; Abdel-Kader \& Luther, 2008) there is need for contemporary complimentary tools to explore strategic options of Management Accounting (Ramljak \& Rogosic, 2012; Cinquini \& Tenucci, 2010). Firms especially the manufacturing ones in developed countries have basically adopted SMATs albeit gradually (Alsoboa, Nawaiseh, Karaki \& Khattab, 2015) but same cannot be advanced for their counterparts in developing economies (Alsoboa et al, 2015; Egbunike, Ogbodo \& Onyali, 2014; Fagbemi, Abogun \& Uadiake, 2013). Notwithstanding the several benefits of SMATs, usage for business prosperity has been challenging especially among manufacturing firms in Nigeria (Egbunike et al 2014; Fagbemi et al 2013) with perceived environmental uncertainty (PEU) a critical reason for non-adoption and usage (Andesto, 2016 ; Al-Mawali, 2015). 
PEU is the unpredictability of the external environments as it affects the operation of a firm (Milliken, 1987). It indicates the inability of top management personnel to correctly forecast their external environment (Tymon, Stout, \& Shaw, 1998). It is the gap between available information and required information in the immediate business environment (Turban, Leidner, Mclean \& Wetherbe, 2008). SMATs are management tools that react to the inadequacies of TMATs in terms of competition and customer sophistication. Failure of firms to react to the environment by adjusting to uncertainty, anticipate change and effectively manage the change (Oetinger, 2004) leads to loss in market position, declining profits, or outright business closure. Previous researches on the subject matter had focused on influence of PEU as moderating the relationship between SMA usage and organizational performance (Cleary, 2015; Ogunsiji \& Akanbi, 2013; Chenhall \& Chapman, 2006; Gerdin \& Greeve, 2004) and the link between PEU and corporate decisions (Westerberg \& Wincent 2008; Agle, Nagarajan, Sonnenfeld \& Srinivasan, 2006; Karimi, Somers and Gupta 2004) but none had empirically studied the relationship between the usage of SMATs and PEU among manufacturing firms in developing countries.

This paper investigates the impact of PEU on SMAT usage among manufacturing firms in Nigeria given the popularity of TMATs usage among manufacturing firms. PEU has a positive influence on management ability to take timely and viable decision (Alsoboa et al, 2015; Ojra, 2014; Ramljak \& Rogosic, 2012) concerning competitors, customers and on macro-economic variables. This study is important for two reasons. First, there is need to evaluate the extent of SMATs usage among manufacturing firms in Nigeria given the existence of external environment on business activities (Akenbor \& Okoye, 2012). Also, the relationship between the mediating role of PEU and SMATs usage among manufacturing firms have resulted in mixed research findings ( Ojra, 2014; Ahmad \& Leftesi, 2014; Ramljak and Rogosic, 2012) hence the need to explore the research findings about Nigerian manufacturing firms. In covering this research gap, this paper makes key contributions to the literature on the subject matter. It provides evidence on the reaction of managers to perceived environmental signals on the usage of SMATs and therefore has potential implications for business policy-makers on how improved business information provided by SMA affect the stability of Nigerian manufacturing firms. Therefore this study gives new insight into the relationship between PEU and the usage of SMATs among Nigerian manufacturing firms, and to test empirically the effect of PEU on usage of SMATs by the firms-which are the objectives of this paper.

The research questions on which this paper attempts to provide answers to are :(i) is there any significant relationship between PEU and the usage of SMATs by Nigerian manufacturing firms? (ii) What are the PEU factors militating against the usage of SMATs among Nigerian manufacturing firms?

The rest of the paper is structured into four parts. Part 2 discusses the literature part 3, the methodology. Part 4 explains the analysis and implications of findings while part 5 is the conclusion and recommendations.

\section{Literature Review}

\section{Perceived Environmental Uncertainty and Strategic Management Accounting Technique}

The Institute of Chartered Accountants of Nigeria (ICAN) in 2010 described SMA 'as the provision and analysis of financial information on the firm's product markets, competitors' cost and cost structures, the monitoring of the enterprise's strategies and those of its competitors in these markets over a number of periods'. The competitors, government influences and 
globalization are components of external environment that firms operate in, these affect their activities and the need for decision making. Hence the usage of various techniques by firms in a globalized economy where business survival is largely based on availability of timely information for management use (Tillmann \& Goddard, 2008).

The external environment (which could be turbulent or stable) is external phenomena that have either potential or actual influence on the organization. The external environment of an organization is composed of all the forces that have direct or indirect influence on its operation. Therefore there is need for a forward looking accounting information system that can withstand uncertain business environment like increasing competition, the consumer and the market dynamism. Environmental changes could be sudden and dramatic leading to dynamic application of business ideas that the deficient traditional managerial process cannot withstanding (Ogunsiji \& Akanbi, 2013; May, Stewart \& Sweo 2000). The external business environment is divided into two categories- the task environment, which has a direct impact, and the remote environment with indirect impacts (Carpenter \& Sander 2009). The task environment consist of customers, suppliers and investors, and competitors, and the remote environment encompasses of six sectors; the political, economic, social-cultural, technological, natural environmental and legal sectors. Task environment is organization-specific- each organization operates in its unique environment while remote environment is general and macro-economic indices influence all firms. However to Pearson II, Robinson \& Mital (2008) firms' external environment are the "factors beyond the control of the firm that influences its choice of direction and action, organizational structure and internal processes". They opined that the external environment can be divided into three interrelated subcategories: factors in the remote environment, factors in the industry environment, and factors in the operating environment.

Perceived environmental uncertainty (PEU) occurs when firms' managements perceived unpredictability in their environment (Buchko 1994), it is the gap between available information and required information. Empirically PEU variables are market turbulence, strategic agility, strategic sensitivity, leadership unity and resource fluidity (Ogunsiji \& Akanbi, 2013).

Schoute (2009) posited that PEU is important because the greater the degree of PEU the higher the firm's need for information which can be obtained through advanced costing system like SMA. Regan (2012) opined that management should take precaution about environmental uncertainty because it is one of the fundamental challenges in the quest of business growth. Hoque, Mia \& Alam (2001) explained firms facing higher competition situation are expected to utilize advanced costing techniques to mitigate the impact on their activities and performance evaluation. Jusoh (2008) in a research survey solely on manufacturing firms discovered that the sector is highly competitive and vulnerable to environmental changes especially from external sources which management has little or no control over. Daft (2004) explained that a firm's environment consists of several factors which have an interaction with the organization strategy decision making. Also, Kotha \& Nair (1995) in their survey concluded that the firm's environment determine the growth and impacted on its profitability based on the reporting standard. Langfield-Smith (2007), Van der Stede, Chow \& Lin (2006) and Chenhall (2003) all agreed that a firm's adopted MATs affect it survival rate in a highly turbulent environment, hence it is pertinent for firms to adopt a scientific and contemporary MATs like SMATs. Bromwich \& Bhimani (1994) stressed the importance of qualitative and non-financial measures in terms of MATs in manufacturing activities due to the importance of the sector to the economy. Waweru, Hoque \& Uliana (2004) found that environmental change in South Africa arising from government deregulation policy and global 
competitive environments contributed to management accounting and control system change processes. Similarly, Lucey (2003) attributed the ability of an organization to withstand the changing external environment influences on its activities to the adaptation to contemporary management accounting system that can cope effectively. Webb, Jeffrey \& Schulz (2010) explained that firms' success and survival depend on their responses to social, economic change, technological, political or government regulations, such responses should be the use of advanced management accounting tools. Ajibolade, Arowomole \& Ojikutu (2010) in their Nigerian study stated that environmental factors influence the implementation and management accounting information system design. In another Nigerian study of the relationship between the perceptions of environmental uncertainty and firms' reaction, Sawyerr (1993) discovered that high political instability in Nigeria affects the choice of a particular management reporting system.

Chenhall and Morris (1986) advanced the importance of PEU by postulating its effect on the firm's information requirements which shows a positive association with the management accounting system. Brownell (1987) agreed Chenhall and Morris (1986) by showing a positive relationship between accounting performance measurements and environment uncertainty. Chenhall (2003) opined that the adoption of efficient management accounting information system is associated with prevailing PEU among business managers. Other scholars (Al-Mawali, 2015) share similar opinion buttressing the fact that the greater the PEU, the higher the propensity of a firm to adopt appropriate MATs. Businesses need more sophisticated accounting information systems to provide more nonfinancial and external information under condition of high environment uncertainty (Al-Mawali, 2015).

In general from the literature reviewed, SMATs usage is greater among firms operating in an unstable and turbulent environment, in which much information is required for decision making process in order to mitigate the uncertainty strategically.

Using the research outcome of Doz \& Kosonen (2008), the variables of PEU are explained thus: Turbulence is change that occurs in the factors or components of an organization's environment, the amount of environmental turbulence closely relates to the degree of uncertainty facing a firm Strategic agility is the ability of a firm to adjust and adapt strategic direction in core business, as a function of strategic ambitions and changing circumstances, and create not just new product and services, but also new business models and innovative ways to create value. Strategic sensitivity is promoted by a combination of a strong external orientation and internally participative strategy process. Leadership unity is the unification of the decision making body in making fast decisions after a strategic situation occurs. Resource fluidity is the reconfiguration of the business systems and redeployment of the resources rapidly after consideration of the internal capabilities.

\section{Tools of Strategic Management Accounting}

Given the various scholarly works of several management accounting researchers particularly Cravens \& Guilding (2001) and Cadez \& Guilding (2008). Five categories of SMATs namely costing; planning, control and performance; strategic decision-making; competitor accounting and customer accounting are explored in this research.

The costing category of SMATs deals with cost accumulation using contemporary standards of comparison for actual and set standard. Unlike TMATs, these costing methods go beyond the internal environment of the firm to cost products and activities in a holistic manner (Imeokparia \& 
Sanusi, 2014; Cravens \& Guilding, 2001). These include attribute costing, activity base costing, life cycle costing, quality costing, target costing, value chain costing and kaizen costing.

The planning, control and performance measurement category applies benchmarking and balance scorecard to evaluate performance overtime using industrial standards or set measurement. Strategic decision making category is the evaluation of costs and measurement outcomes, the weighing of several alternatives and the science and art of choosing one. These are strategic costing, strategic pricing, brand valuation, brand budgeting, social management accounting and environmental management accounting. Competitor accounting category assesses the strengths, weaknesses, opportunities and threats of competitors relative to the firm's. Competitor cost assessment, Competitor's position monitoring and Competitor performance appraisal are tools of competitors accounting. With customer profitability analysis, life customer profitability analysis and value of customer as asset a firm is able to analyze it marketing arm by evaluating the value and loyalty of customers.

Base on the principle applied by Cadez \& Guilding (2008) the following classifications will be used with modifications.

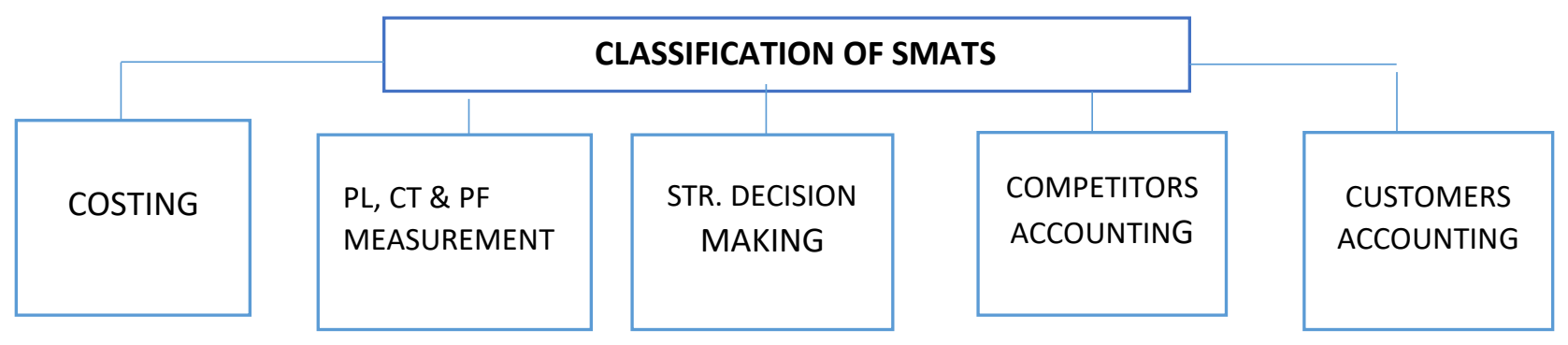

Based on the foregoing, the following hypotheses in their null forms are proposed:

$\mathbf{H}_{\mathbf{0}}$ There is no significant relationship between PEU and the usage of SMATs by Nigerian manufacturing firms.

$\mathbf{H}_{\mathbf{0}}$ There is no PEU factors militating against the adoption of SMATs by Nigerian manufacturing firms.

\section{Research Method}

The cross-sectional survey research method was adopted in this study. Survey research is concerned with identifying real nature of problem and formulating relevant hypothesis to be tested. The use of survey research method is justified because it follows a correlational research strategy and assists in predicting behaviour (Bordens and Abbott, 2002). It also helps to determine whether or not relationships exist between the variables of study (Ahmad, 2012). Data were collected using a self-distributed questionnaire instrument from manufacturing firms operating in the Agbara Industrial Estate, Ogun State, Nigeria which is the population of the study. According to the available records of the Industrial Estate administrators, a total of 233 firms operate therein as at December 2017. The Industrial Estate was chosen because of the convergence of several types of manufacturing outfits in the same area and can conveniently provide information for this study. A sample of 147 manufacturing was chosen based on random sampling and the number was arrived at by applying Burley's formula popularised by Yamane (1973) and applied by Udeze (2015) stated as: $\mathrm{n}=\mathrm{N} /\left[1+\mathrm{N}\left(\mathrm{e}^{2}\right)\right]$, Where, $\mathrm{n}=$ Sample Size; $\mathrm{N}=$ Population Size; e= desired level of significance $(5 \%)$. Therefore, $n=233 /\left\{1+233\left(0.05^{2}\right)\right\}, n=233 / 1.5825, n=147$. A pilot survey was adopted for the reliability test, and it yielded correlation coefficient of 0.62 .120 questionnaires 


\section{1 | International Journal of Scientific and Management Research 4(4) 106-118}

were returned fully filled, an $82 \%$ pass. According to Saunders, Lewis \& Thornhill (2007) the likely response rate for business surveys is between 30-50 per cent for self-administered questionnaires. Thus, this response rate obtained from this study is considered to be very satisfactory.

Relevant statistical tools such as the percentages and tables are used for the data analysis. The hypotheses were analyzed using a survey questionnaire. It was structured in line with the research questions. Pearson Product Moment Correlation Coefficient, simple statistical tools and regression analysis (Ordinary Least Square (OLS) with the aid of SPSS 20) were used for data analysis. These tools of data analysis measure the association between PEU and the usage of SMATs by Nigerian manufacturing firms.

\section{Variable measurement}

\section{SMA usage}

The extent of SMATs usage was measured using the same instrument applied by prior studies (AlMawali, 2015; Cadez \& Guilding; 2008). The respondents were asked to indicate to what extent does their firm use listed SMATs in their management accounting reports? The 22 SMA techniques were listed together with a Likert-type scale ranging 5 Likert scale response options of Strongly Agreed (SA), Agreed (A), No Effect (NE) Disagree (D), and Strongly Disagreed (SD) with weights of 5,4,3,2 and 1 respectively. A glossary containing operational meaning of the SMATs was provided to aid responses.

\section{PEU}

PEU refers to the emergence of threats and opportunities that make assumptions the basis for determining the strategy (Simons, 2000). Perception in this research is the predictability and stability with regard to the differences between the information held by managers and required information (Gordon \& Narayanan, 1984). The current study has measured PEU using the same instrument applied by Al-Mawali (2015) and Kren \& Kerr (1993) with modification by bringing in the five variables of market turbulence, strategic agility, strategic sensitivity, leadership unity and resource fluidity. The respondents were requested to indicate their perception about the predictability regarding their organization's factors (including; customers, suppliers, government policies, competitors, and technologies) on a five-point numerical scale anchored at (1) Strongly Disagreed and (5) strongly Agreed.

\section{Model Specification}

The model of this research explains the influence of PEU on SMATs usage. The independent variables were formed by adopting the scales consisting of five terminologies applicable to PEU in the investigation of SMATs usage. In order to measure the relationship, this study adopted with modifications the model in Al-Mawali (2015).

SMATu $=\alpha_{0}+\beta_{1}$ MKTU $_{\mathrm{it}}+\beta_{2} \mathrm{SAGL}_{\mathrm{it}}+\beta_{3} \mathrm{SSEN}_{\mathrm{it}}+\beta_{4} \mathrm{LDUN}_{\mathrm{it}}+\beta_{5} \mathrm{RSFL}_{\mathrm{it}}+\beta_{7} \mathrm{SIZE}_{\mathrm{it}}+\mathrm{e}_{\mathrm{it}}$

SMATu $=$ Strategic Management Accounting Techniques usage

$\alpha_{0}=$ constant, $\beta_{\mathrm{t}-7}=$ co-efficient

MKTU $=$ Market turbulence $($ MKT_TUBL)

SAGL $=$ strategic agility $($ STR_AGL) 
SSEN = strategic sensitivity (STR_SENL)

LDUN = leadership unity (LDR_UNT)

RSFL= resource fluidity (RSR_FLU)

SIZE $=$ Firm size (FIRM _SIZE)

$\mathrm{e}_{\mathrm{t}}=$ Error term

Adapted from Al-Mawali (2015) and Fagbemi et al (2013).

The above model is consistent with the contingency theory (PEU as a key variable) in which firm's behaviour is affected by contextual variables from their external environment (Al-Mawali, 2015; Fagbemi et al, 2013).

\section{Data Presentation, Analysis and Interpretation}

\section{Test of Hypothesis}

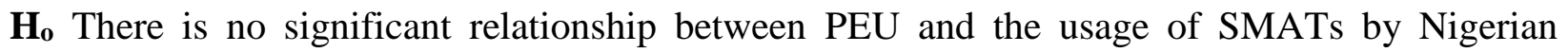
manufacturing firms.

$\mathbf{H}_{\mathbf{0}}$ There is no PEU factor militating against the adoption of SMATs by Nigerian manufacturing firms.

Hypothesis 1: There is no significant relationship between PEU and the usage of SMATs by Nigerian manufacturing firms.

This hypothesis was tested based on the responses in tables 1 and 3, using the ranking method, it can be deduced that changes in production technology, globalization impact and macroeconomic factors (ranked first, second and third respectively) accounted for environmental factors that makes SMATs usage unavoidable by the firms. The mean, standard deviation and Z-score values concurred with the ranking assertion all returning above average values. Hence there is a significant relationship between PEU and the usage of SMATs by Nigerian manufacturing firms. However, management accounting reports were not prepared based on SMA (ranked last) despite the respondents' acknowledgement of the influence of the business environment.

Additionally, table 1 shows the correlational values among PEU variables of market stability, strategic agility, strategic sensibility, leadership unity, resource fluidity and management perception and the usage of SMATs. With the co-efficients ranging from 0.56 and 0.99 , it can be concluded that none of the variables is below 0.5 benchmark of acceptance. Hence hypothesis 1 is hereby rejected, there is significant relationship between PEU and the usage of SMATs by Nigerian manufacturing firms. The greater the level of PEU, the higher the propensity of SMATs usage by manufacturing firms.

Hypothesis 2: There is no PEU factor militating against the adoption of SMATs by Nigerian manufacturing firms.

Using table 3, the calculated mean and standard deviation indicate the closeness of PEU factors because of their closeness, while the mean is between 3.84 and 4.48 all above the average of 3 , and the standard deviation between 1.64 and 2.04 hence showing the closeness of all the militating factors. Applying ranking, management perception is the foremost factor militating against the adoption of SMATs (Ojua, 2016), while lack of strategic sensibility was ranked sixth as PEU factor that affect the adoption of SMATs. From the foregoing, the second hypothesis is rejected confirming that PEU factors are responsible for the non-adoption of SMATs by Nigerian manufacturing firms. 


\section{3 | International Journal of Scientific and Management Research 4(4) 106-118}

To buttress the assertion on hypothesis 2, applying Z-statistics given the stated population mean of ' 3 ' with the z-score in order, as follows 4.26,3.79,3.62,4.08,3.77 and 5.10 thus using the principle of any score below ' 3 ' is outside the range, hence all the PEU factors are above 3, implying that PEU factors militate against the adoption of SMATs.

\section{Conclusions and Recommendation}

A good use of PEU by management makes decision making and policy formulation effortlessly achievable and the benefits thereon especially on competition meaningful. The objective of this study is to investigate the impact of PEU on the usage of SMATs by Nigerian manufacturing firms. Hypothesis 1 was tested using simple statistical tools and correlation co-efficient calculated from the data collected through questionnaire. The Correlation Coefficients were calculated to show relationship between PEU factors and SMATs usage with values ranging from 0.56 and 0.99 , it can be concluded that none of the variables is below 0.5 benchmark of acceptance. Hence the null hypothesis is rejected and concluded that there is significant relationship between PEU and SMATs' usage among manufacturing firms. For hypothesis 2, the applied approach by using statistical tools and Z-statistics of assumed population mean ' 3 ' to ascertain the PEU factors usage of SMATs by manufacturing firms. The results indicated that all PEU factors including management perception militate against the usage of SMATs among Nigerian manufacturing firms.

These results show that management of Nigerian manufacturing firms respond positively to Perceived Environmental Uncertainty in the usage of SMATs. While SMAT usage is essential to make management accounting report strategic for effective decision making, it usage by Nigerian manufacturing firms could be achievable if managements of the firms react to PEU promptly to avoid being left behind. Effective leadership, strategic re-ordering and resource viability will ensure business environmental signals are decoded to ensure the right SMA technique(s) is deplored to meet possible challenges, the sustenance of such will eventually put the firms in strong position to compete effectively in the competitive marketplace.

\section{References}

1) Abdel-Kader, M. \& Luther, R. (2008). Management accounting practices in the British food and drinks industry. British Food Journal, 108(5), 336-357.

2) Agle, B. R., Nagarajan, N., Sonnenfeld, J. A., and Srinivasan, D. (2006). Does CEO Charisma Matter? An Empirical Analysis of the Relationships among Organizational Performance, Environmental Uncertainty, and Top Management Team Perceptions of CEO Charisma. Academy of Management Journal, 49(1), 161-174.

3) Ahmad, K. (2012). The adoption of management accounting practices in Malaysian small and medium-sized enterprises. Asian Social Science, 10(2), 236-249.

4) Ahmad, M. \& Leftesi, A. (2014). An exploratory study of the level of sophistication of management accounting practices in Libyan manufacturing companies. International Journal of

5) Business and Management 2 (2), 1-10.

6) Ajibolade, SO., Arowomole, Ojikutu, R.K. 2010. Management accounting systems, perceived environment uncertainty and companies' performance in Nigeria. International Journal of Academic Research, 2 (1) 195-201. 
7) Al-Mawali, H. (2015). Strategic management accounting usage, environmental uncertainty and organizational performance. European Journal of Business and Management, 7(8), 219-234.

8) Alsoboa, S., Al Khattab, A, \& Al-Rawad, M. (2015). The extent to which the Jordanian private industrial companies Use SMA Techniques. European Journal of Business and Management, 7(7), 456-465.

9) Andesto R. (2016). The influence of perceived environmental uncertainty and business strategy on management accounting system (survey on the Indonesia advertising companies). European Journal of Accounting, Auditing and Finance Research, 4,(3), 27 36.

10) Bhimani, A., \& Bromwich, M. (1994). Advanced manufacturing technology and accounting: A renewed alliance. Advanced Manufacturing Engineering, 5(3), 199-207.

11) Bordens, S.K, \& Abbott, B.B. (2002). Research Design and Methods: A Process Approach (5th Ed.) New York: McGraw-Hill.

12) Brownell, P. (1987). The role of accounting information, environment and management control in multinational organization. Accounting and Finance, 27, 1-11.

13) Buchko, A (1994) Conceptualization and measurement of environmental uncertainty: An assessment of the Miles and Snow perceived environmental uncertainty scale Academy of Management Journal , 3 (1), 410-425

14) Cadez, S., \& Guilding, C. (2008). An exploratory investigation of an integrated contingency model of strategic management accounting. Accounting, Organizations and Society, 33(7-8), 836-863.

15) Chenhall RH \& Morris D (1986). The impact of structure, environment and interdependence on the perceived usefulness of management accounting systems, Acc. Rev., 61, 16-35.

16) Chenhall, R. H. (2003). Management Control Systems Design Within its Organizational Context: Findings from Contingency-based Research and Directions for the Future Accounting, Organizations and Society 28(2/3), 127-168.

17) Cinquini, L., \& Tenucci, A. (2010). Strategic management accounting and business strategy: A loose coupling? Journal of Accounting \& Organizational Change, 6(2), 228259.

18) Cleary, P. (2015). An Empirical Investigation of the Impact of Management Accounting on Structural Capital and Business Performance. Journal of Intellectual Capital, 16 (3), $566-586$.

19) Cravens, K.S., \& Guilding, C. (2001). An empirical study of the application of strategic management accounting techniques. Advances in Management Accounting, 10, 95-124.

20) Daft, R. L. (2004). Organizational theory and design. 8th edition. Thompson Southwestern.

21) Doz Y, \& Kosonen M (2008), The Dynamics of Strategic Agility: Nokia's Rollercoaster Experience, California Management Review, 50(3), 95-118.

22) Egbunike, F, Ogbodo, C., \& Onyali, A. (2014). Utilizing strategic management accounting techniques for sustainability performance measurement. Research journal of Finance and Accounting, 5(3), 140-153.

23) Fagbemi, T.,Abogun,S. \& Uadiale, O.(2013). Appraisal of the adoption of cost management techniques in selected Nigerian manufacturing companies. KASU Journal of Accounting Research and Practice, 2(2), 1-13. 
24) Gerdin, J., \& Greve, J. (2004). Forms of contingency fit in management accounting research: A critical review. Accounting, Organizations and Society, 29(3-4), 303-326.

25) Gordon LA, Narayanan VK (1984). Management accounting systems, perceived environmental uncertainty and organizational structure: an empirical investigation, Acc. Org. Soc., 9(1): 33-47

26) Hoque, Z., Mia, L. and Alam, M. (2001). Market competition, computer-aided manufacturing and use of multiple performance measures: An empirical study. British Accounting Review 33, 23-45.

27) ICAN Study Pack (2010). Business communications and research methodology. Lagos: VI Publishers.

28) Imeokparia, L. \& Sanusi, A. (2014). Target costing and performance of manufacturing industry in South-Western Nigeria. Global Journal of Management and business research, 14(4), 51-60.

29) Jusoh, R. (2008). Environmental Uncertainty, Performance, and the Mediating Role of Balanced Scorecard Measures Use: Evidence from Malaysia. International Review of Business Research Papers, 4(2) 116-135.

30) Lucey, T. (2003). Management Accounting ( $5^{\text {th }}$ Ed). London. Continuum

31) Karimi, J., Somers, T. and Gupta, Y. (2004). Impact of Environmental Uncertainty and Task Characteristics on User Satisfaction with Data. Information Systems Research, 15 (2): 175-184.

32) Kotha, Suresh and Nair, Anil (1995). Strategy and environment as determinant of performance: Evidence from the Japanese machine tool industry, Strategic Management Journal, 16(7), 497-518.

33) Kren, L. and J. L. Kerr. (1993). the effect of Behaviour Monitoring and Uncertainty on the use of Performance-contingent Compensation. Accounting and Business Research, 23, 159-168.

34) Langfield-Smith, K., 2007, A Review of Quantitative Research in Management Control Systems and Strategy, in: C. S. Chapman, A. G. Hopwood, and M. D. Shields, eds., Handbook of Management Accounting Research, Vol. 1 (Elsevier: Oxford, UK), 753-784).

35) May, R. C., Stewart, W. H. J. \& Sweo, R. (2000). Environmental scanning behavior in a transitional economy: evidence from Russia. Academy of Management Journal, 43, 403-427.

36) Milliken, F. J (1987). Three types of perceived environmental uncertainty about the environment: State, effect, and response uncertainty. Acad. Manage. Rev., 12, 133-143.

37) Oetinger, B. V. (2004). A plea for uncertainty: Everybody complains about uncertainty, but it might be a good thing to have. Journal of Business Strategy. 25 (1), 57-59.

38) Ogunsiji, A. S. \& Akanbi, P. A. (2013). The Role of Perceived Environmental Uncertainty and Strategic Agility on the Performance of Selected Banks in Oyo State of Nigeria. Information and Knowledge Management www.iiste.org, 3 (7), 23-32.

39) Ojra,J. (2014). Strategic management accounting practices in Palestinian companies: Application of contingency theory perspective. A doctorate thesis submitted at Norwich Business School, University of East Anglia, United Kingdom.

40) Ojua, O.M. (2016). Management perceptions of the role of strategic management accounting techniques in decision making: A survey of Nigerian petroleum marketing. Imperial Journal of Interdisciplinary Research, 2(8), 1-10.

41) Pearson II, J. A., Robinson Jr, R. B. \& Mital, A. (2008). Strategic management: formulation, implementation, and control, Tata McGraw-Hill 
42) Ramljak, B., \& Rogoši ć, A., (2012). Strategic management accounting practices in Croatia. The Journal of International Management Studies, 7(2), 93-100.

43) Regan, P. (2012). Making Sense of Uncertainty: An Examination of Environmental Interpretation. International Journal of Business and Management, 7(6), 18-29.

44) Saunders, M., Lewis, P. \& Thornhill, A. (2007). Research Methods for Business Students, 4th edition, Financial Times Prentice Hall, Harlow.

45) Sawyerr, O. 1993. Environmental uncertainty and environmental scanning activities of Nigerian manufacturing executives: A comparative analysis. Strategic Management Journal 14: 287-299.

46) Schoute, M. (2009). The relationship between cost system complexities, purposes of use, and cost system effectiveness, The British Accounting Review, 41, 208-226.

47) Sidhu, B.K. \& Roberts, J.H. (2008). The marketing/accounting interface: lessons and limitations. Journal of Marketing Management, 24(7-8), 669-686.

48) Tillman, K., Goddard, A., (2008), Strategic management accounting and sense-making in a multinational company. http://eprints.soton.ac.uk/346737/ (downloaded: 01.05.2016).

49) Turban E, Leidner D, Mclean E, Wetherbe J (eds.) (2008), Information Technology Management: Transforming Organizations in the digital Economy. John Wiley \& Sons Ltd.

50) Tymon, W. G., Stout, D. E., and Shaw, K. N. (1998). Critical Analysis and Recommendations Regarding the Role of Perceived Environmental Uncertainty in Behavioural Accounting Research. Behavioural Accounting Research, 10, 23-46.

51) Udeze, $C$ (2015). Change management and its effects on employees' performances in the Nigerian manufacturing firms. Ebonyi State University Journal of contemporary management, 3, 103-108.

52) Van der Stede, W. A., Chow, C. W. and Lin, T. W. (2006). Strategy, Choice of Performance Measures, and Performance. Behavioral Research in Accounting . 18, 185-205.

53) Waweru, M. N., Hoque, Z. \& Uliana, E. (2004). Management accounting change in South Africa: Case studies from retail companies, Accounting, Auditing and Accountability Journal, 17 (5), 675-704.

54) Webb, A., S. A. Jeffrey and A. Schulz. (2010). Factors affecting goal difficulty and performance when employees select their own performance goals: Evidence from the field. Journal of Management Accounting Research (22): 209-232

55) Westerberg, Mats and Wincent, Joakim. (2008). CEO Succession, Honing, and Enterprising: A Promising Way to Achieve Small Business Performance. Journal of Developmental Entrepreneurship, 13( 2), 117-132.

\section{Works Cited}

OJUA, Olusegun Michael. (2021). The Role of Perceived Environmental Uncertainty on the usage of Strategic Management Accounting Techniques among Nigerian Manufacturing firms. International Journal of Scientific and Management Research, 04(04), 106-118. doi:http://doi.org/10.37502/IJSMR.2021.4408 
Table 1: Correlation co-efficients of PEU factors

\begin{tabular}{|l|l|l|l|l|l|l|}
\hline PEU factors & $\begin{array}{l}\text { Mkt } \\
\text { Stab. }\end{array}$ & $\begin{array}{l}\text { Stra. } \\
\text { Agility }\end{array}$ & Stra. Sens. & $\begin{array}{l}\text { Leader. } \\
\text { Unity }\end{array}$ & $\begin{array}{l}\text { Resource } \\
\text { Fluidity }\end{array}$ & $\begin{array}{l}\text { Mgt } \\
\text { Percep }\end{array}$ \\
\hline $\begin{array}{l}\text { Market } \\
\text { stability }\end{array}$ & 1 & & & & & \\
\hline $\begin{array}{l}\text { Strategic } \\
\text { Agility }\end{array}$ & 0.94 & 1 & 0.99 & 1 & & \\
\hline $\begin{array}{l}\text { Strategic } \\
\text { Sensibility }\end{array}$ & 0.92 & 0.83 & 0.81 & 1 & & \\
\hline $\begin{array}{l}\text { Leadership } \\
\text { Unity }\end{array}$ & 0.72 & 0.96 & 0.95 & 0.75 & 1 & \\
\hline $\begin{array}{l}\text { Resource } \\
\text { Fluidity }\end{array}$ & 0.86 & 0.76 & 0.74 & 0.56 & 0.68 & 1 \\
\hline $\begin{array}{l}\text { Mgt } \\
\text { Perception }\end{array}$ & 0.66 & 0.96 & & \\
\hline
\end{tabular}

Table 2: Responses on relationship between PEU and the usage of SMATs

\begin{tabular}{|c|c|c|c|c|c|c|c|c|c|}
\hline Responses & 5 & 4 & 3 & 2 & 1 & Mean & Rank & SD & $\begin{array}{l}\text { Z- } \\
\text { stat }\end{array}$ \\
\hline $\begin{array}{l}\text { SMATs are being used by your } \\
\text { organization to prepare } \\
\text { management accounting reports. }\end{array}$ & $\begin{array}{l}35 \\
24 \\
\%\end{array}$ & $\begin{array}{l}20 \\
14 \%\end{array}$ & $\begin{array}{l}15 \\
10 \%\end{array}$ & $\begin{array}{l}30 \\
20 \%\end{array}$ & $\begin{array}{l}47 \\
32 \%\end{array}$ & 2.7 & 6 & 1.43 & - \\
\hline $\begin{array}{l}\text { SMATs usage is made popular by } \\
\text { changes in production technology }\end{array}$ & $\begin{array}{l}67 \\
46 \%\end{array}$ & 30 & 25 & $7 \%$ & 15 & 3.8 & 1 & 1.65 & 3.62 \\
\hline $\begin{array}{l}\text { Industrial standards and norms } \\
\text { made SMATs usage inevitable }\end{array}$ & $\begin{array}{l}45 \\
31 \% \\
\end{array}$ & $\begin{array}{l}32 \\
22 \% \\
\end{array}$ & $\begin{array}{l}20 \\
14 \% \\
\end{array}$ & $\begin{array}{l}25 \\
16.5 \% \\
\end{array}$ & $\begin{array}{l}25 \\
16.5 \% \\
\end{array}$ & 3.3 & 5 & 1.45 & 1.56 \\
\hline $\begin{array}{l}\text { Globalization makes SMATs usage } \\
\text { among manufacturing firms } \\
\text { seamless }\end{array}$ & $\begin{array}{l}57 \\
37 \% \\
\end{array}$ & $28 \%$ & $\begin{array}{l}20 \\
14 \% \\
\end{array}$ & $\begin{array}{l}20 \\
14 \% \\
\end{array}$ & $7 \%$ & 3.7 & 2 & 1.61 & 3.40 \\
\hline $\begin{array}{l}\text { Macro-economic factors and fiscal } \\
\text { policy swings created need for } \\
\text { SMATs }\end{array}$ & $\begin{array}{l}45 \\
31 \%\end{array}$ & $\begin{array}{l}55 \\
37 \% \\
\end{array}$ & $\begin{array}{l}17 \\
12 \%\end{array}$ & 25 & $\begin{array}{l}5 \\
3 \% \\
\end{array}$ & 3.75 & 3 & 1.60 & 3.31 \\
\hline 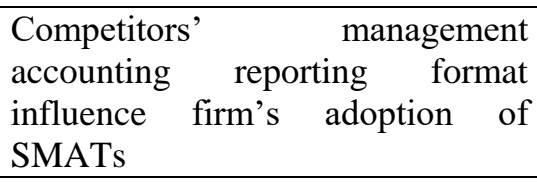 & $\begin{array}{l}45 \\
31 \%\end{array}$ & $\begin{array}{l}55 \\
37 \%\end{array}$ & $5 \%$ & $\begin{array}{l}25 \\
17 \%\end{array}$ & $\begin{array}{l}15 \\
10 \%\end{array}$ & 3.61 & 4 & 1.54 & 2.81 \\
\hline
\end{tabular}

Source: Researcher's computation 
118 International Journal of Scientific and Management Research 4(4) 106-118

Table 3: Responses to PEU factors hindering the usage of SMATs

\begin{tabular}{|c|c|c|c|c|c|c|c|c|c|}
\hline Responses & 5 & 4 & 3 & 2 & 1 & Mean & Rank & SD & $\begin{array}{l}\text { Z- } \\
\text { stat }\end{array}$ \\
\hline $\begin{array}{l}\text { Market stability without turbulence } \\
\text { in the manufacturing sector } \\
\text { encourages SMATs and modern } \\
\text { techniques usage }\end{array}$ & $\begin{array}{l}75 \\
51 \%\end{array}$ & $\begin{array}{l}37 \\
25 \%\end{array}$ & $\begin{array}{l}15 \\
10 \%\end{array}$ & $\begin{array}{l}10 \\
7 \%\end{array}$ & $\begin{array}{l}10 \\
7 \%\end{array}$ & 4.07 & 2 & 1.77 & 4.26 \\
\hline $\begin{array}{l}\text { The ability of manufacturing firms to } \\
\text { withstand market variations through } \\
\text { strategic agility leads to SMATs }\end{array}$ & $\begin{array}{l}55 \\
37 \%\end{array}$ & $\begin{array}{l}57 \\
39 \%\end{array}$ & $\begin{array}{l}10 \\
7 \%\end{array}$ & $\begin{array}{l}15 \\
10 \%\end{array}$ & $\begin{array}{l}10 \\
7 \%\end{array}$ & 3.90 & 4 & 1.68 & 3.79 \\
\hline $\begin{array}{l}\text { Lack of strategic sensibility via } \\
\text { company's policy hinders the usage } \\
\text { of SMATs }\end{array}$ & $\begin{array}{l}80 \\
54 \%\end{array}$ & $\begin{array}{l}17 \\
12 \%\end{array}$ & $\begin{array}{l}17 \\
12 \%\end{array}$ & $\begin{array}{l}13 \\
8 \%\end{array}$ & $\begin{array}{l}20 \\
14 \%\end{array}$ & 3.84 & 6 & 1.64 & 3.62 \\
\hline $\begin{array}{l}\text { The quality of management } \\
\text { (leadership unity) among } \\
\text { manufacturing firms makes SMATs } \\
\text { usage unattainable }\end{array}$ & $\begin{array}{l}55 \\
37 \%\end{array}$ & $\begin{array}{l}57 \\
39 \%\end{array}$ & $\begin{array}{l}20 \\
14 \%\end{array}$ & $\begin{array}{l}10 \\
7 \%\end{array}$ & $3 \%$ & 4 & 3 & 1.73 & 4.08 \\
\hline $\begin{array}{l}\text { Resource fluidity-the ability to mix } \\
\text { available business resources by } \\
\text { management affect SMAT usage }\end{array}$ & $\begin{array}{l}60 \\
40 \%\end{array}$ & $\begin{array}{l}40 \\
28 \%\end{array}$ & $\begin{array}{l}25 \\
17 \%\end{array}$ & 15 & $5 \%$ & 3.89 & 5 & 1.67 & 3.77 \\
\hline $\begin{array}{l}\text { Management perception of SMA } \\
\text { affects the usage of SMATs among } \\
\text { manufacturing firms. }\end{array}$ & $\begin{array}{l}100 \\
68 \%\end{array}$ & $\begin{array}{l}32 \\
22 \%\end{array}$ & $\begin{array}{l}5 \\
3.33 \%\end{array}$ & $\begin{array}{l}5 \\
3.33 \%\end{array}$ & $\begin{array}{l}5 \\
3.34 \%\end{array}$ & 4.48 & 1 & 2.04 & 5.10 \\
\hline
\end{tabular}

Source: Researcher's computation 